Original Paper

\title{
Penyuluhan Tehnik Pembedahan Hewan Coba Untuk Mengamati Struktur dan Frekwensi Denyut Jantung Pada Siswa SMP Negeri 7 Mataram
}

\author{
I Wayan Merta ${ }^{1 *}$, Imam Bachtiar ${ }^{1}$, Syachruddin AR $^{1}$, Kusmiyati $^{1}$ \\ ${ }^{1}$ Program Studi Pendidikan Biologi Fakultas Keguruan dan Ilmu Pendidikan, Universitas Mataram
}

*Corresponding Author: I Wayan Merta, Program Studi Pendidikan Biologi Fakultas Keguruan dan Ilmu Pendidikan, Universitas Mataram, Indonesia;

Email:

wayanmerta.fkip@unram.ac.id

\begin{abstract}
Abstrak: Teknik pembedahan merupakan pengetahuan tentang cara-cara pembedahan hewan coba untuk mengamati organ-organ dalam. Keberasilan pengamatan struktur dan frekwensi denyut jantung pada hewan coba sangat ditentukan oleh tehnik-tehnik pembedahan. Pengabdian ini bertujuan untuk meningkatkan pengetahuan siswa tentang tehnik-tehnik pembedahan hewan coba dan meningkatkan ketrampilan siswa melakukan pembedahan hewan coba untuk mengamati struktur jantung dan frekwensi denyut jantung. Metode dalam pengabdian ini dilakukan dengan metode penyuluhan, pada tahap ini disampaikan materi tentang tehnik-tehnik pembedahan hewan coba dan metode pratekum, yaitu melakukan praktek pembedahan hewan coba untuk mengamati struktur jantung dan frekwensi denyut jantung. Hewan coba yang digunakan dalam pengabdian ini adalah 10 ekor mencit (Mus musculus) strain BALB/C dan 10 ekor dan katak (Rana $S p$ ). Pengabdian ini dapat disimpulkan: Kegiatan pengabdian ini sangat bermanfaat bagi siswa Klas VII SMP Negeri 7 Mataram sebagai pengetahuan dan ketrampilan terkait dengan tehnik pembedahan hewan coba. Siswa telah memahami tehnik-tehnik pembedahan hewan coba, dapat melakukan pembedahan hewan coba dengan baik dan benar, serta mengetahui struktur jantung Katak dan Mencit. Hasil praktekum diperoleh Mencit memiliki rata-rata denyut jantung 102 per menit, sedangkan denyut jantung Katak reratanya 69 per menit.
\end{abstract}

Kata Kunci: Katak (Rana sp),Mencit (Mus musculus),dan Frekwensi denyut jantung

\section{Pendahuluan}

Teknik pembedahan merupakan pengetahuan tentang cara pembedahan hewan coba untuk mengamati organ-organ dalam. Keberasilan pengamatan organ - organ dalam dan frekwensi denyut jantung pada hewan coba sangat ditentukan oleh tehnik-tehnik pembedahan. Frekwensi denyut jantung pada hewan tergantung dari spesies hewan. Pada mencit (mus musculus) frekwensi denyut jantungnya sekitar 98 per menit sedangkan pada katak (Rana sp) sekitar 73 per menit (Ayda. T.Y, dan Sudarwati. S, 1992).

Tehnik pembedahan pada hewan coba untuk mengamati frekwensi denyut jantung dan struktur organ-organ dalam dapat dilakukan dengan cara : Hewan coba misalnya mencit dan katak yang dijadikan sampel dibius dengan kapas yang sudah dibasuh dengan klorofom, rongga abdomen di bedah kearah rongga dada. Selanjutnya rongga dada/thorax dibedah sehingga kelihatan jantungnya, kemudian dilakukan pengamatan frekwensi denyut jantung dan organ-organ dalam. Selama mengamati frekwensi denyut jantung hewan coba tersebut tetap diberikan larutan ringer supaya hewan coba tetap hidup (Nawangsari, 1989).

Di SMPN 7 Mataram pada mata pelajaran IPA khususnya biologi dituntut adanya kegiatan praktikum. Pelaksanaan kegiatan praktikum sering mengalami hambatan terutama melakukan pembedahan hewan coba untuk mengamati struktur organ-organ dalam dan frekwensi denyut jantung. Hambatan yang sering dihadapi siswa, siswa belum sempat mengamati denyut jantung hewan coba keburu mati, dan tidak mendapat struktur organorgan dalam, dalam keadaan utuh karena sudah tercampur aduk. Kesalahan ini disebabkan oleh siswa yang belum paham tentang tehnik pembedahan pada hewan coba. Untuk itu perlu adanya edukasi untuk meningkatkan pengetahuan 
dan ketrampilan tentang tehnik pembedahan hewan coba untuk mengamati struktur organ-organ dalam dan frekwensi denyut jantung.

Tujuan pengabdian ini untuk meningkatkan pengetahuan peserta didik/siswa tentang tehniktehnik pembedahan hewan coba. Meningkatkan ketrampilan peserta didik/siswa membedah hewan coba untuk mengamati struktur jantung dan frekwensi denyut jantung. Manfaat Kegiatan pengabdian ini, diharapkan peserta didik/siswa memiliki pengetahuan tentang tehnik-tehnik pembedahan hewan coba serta memiliki ketrampilan membedah hewan coba untuk mengamati struktur organ-organ dalam dan frekwensi denyut jantung. Permasalahan dan Solusi yang Ditawarkan: Permasalahan, siswa dalam melaksanakan kegiatan praktikum sering mengalami kesulitan terutama melakukan pembedahan hewan coba untuk mengamati struktur organ-organ dalam dan aktivitas/frekwensi denyut jantung.

Hambatan yang sering dihadapi oleh siswa, siswa belum sempat mengamati dan menghitung frekwensi denyut jantung, hewan coba sudah keburu mati, serta tidak dapat mengamati struktur organ-organ dalam, dalam keadaan utuh karena sudah tercampur aduk. Solusi yang ditawarkan, Memberi penyuluhan tentang tehnik-tehnik pembedahan hewan coba dan melakukan praktek pembedahan hewan coba untuk melihat struktur organ-organ dalam dan aktivitas/frekwensi denyut jantung.

Target Luaran, target yang ingin dicapai dalam pengabdian ini adalah 1) meningkatkan pengetahuan peserta didik/siswa tentang tehniktehnik pembedahan hewan coba. 2) meningkatkan ketrampilan peserta didik/siswa dalam praktek membedah hewan coba 3) mengamati struktur jantung dan frekwensi denyut jantung.

\section{Metode Pelaksanaan}

Metode pelaksanaan kegiatan pengabdian masyarakat ini difokuskan pada upaya penyelesaian masalah yang dihadapi oleh siswa SMPN 7 Mataram, yaitu: 1) metode penyuluhan untuk meningkatkan pemahaman dan pengetahuan peserta didik/siswa tentang tehnik-tehnik pembedahan hewan coba. 2) metode praktekum, untuk meningkatkan ketrampilan peserta didik/siswa membedah hewan coba 3) metode pengamatan, untuk mengamati struktur organ-jantung dan frekwensi denyut jantung.

\section{Hasil dan Pembahasan}

Kegiatan pengabdian pada masyarakat dilakukan dua tahap. Tahap pertama penyampaian materi tentang tehnik-tehnik pembedahan hewan coba dan struktur jantung serta cara menghitung frekwensi denyut jantung. Pada saat pelaksanaan kegiatan, antusias peserta cukup tinggi, hal ini dapat dilihat dari banyaknya pertanyaan yang diajukan peserta yang terkait dengan materi yang disampaikan tim pengabdian pada saat diskusi. Selain itu, siswa terlihat sangat antusias ketika melakukan praktek membedah hewan coba. Pada saat pelaksanaan kegiatan pengabdian ini, muncul pertanyaan dari salah satu peserta/siswa menanyakan bagaimana struktur jantung Mencit dan Katak, apa fungsinya, serta bagaimana peredaran darahnya? Berdasarkan pertanyaan tersebut maka, dijelaskan tentang Sistem peredaran darah terdiri dari jantung (cor), pembuluh-pembuluh darah dan darah. Jantung memilki sifat sebagai berikut: Iritabilitas, yaitu kemampuan jantung untuk mengadakan tanggapan bila mendapat rangsangan dengan itensitas yang cukup besar; Daya hantar (konduktivitas), ialah kemampuan jantung untuk merambatkan impuls; Daya kontraksi (kontraktilitas), ialah kemampuan jantung untuk berkontraksi; Keotomatisan, ialah kemampuan jantung untuk berdenyut dengan sendirinya tanpa ada impuls yang datang dari luar jantung; Mempunyai periode refrakter relative lama, refrakter adalah saat yang menunjukkan bahwa jaringan hidup kehilangan sifat iritabilitas; Dan jantung memiliki sifat mengikuti hukum Sterling, bila otot jantung mengembang, yang berarti otot jantung makin panjang, kuat kontraksi otot jantung makin kuat (Kartolo, 1993).

Persarafan jantung, ada dua macam saraf yang mensarafi jantung. Kedua saraf tersebut adalah saraf vagus yang termasuk saraf simpatik dan parasimpatik. Kedua-duanya tergolong dalam sistem saraf otonom. Pengaruh saraf parasimpatik terhadap jantung yaitu menurunkan frekwensi denyut jantung (pengaruh kronotropik negatif), 
menurunkan kuat kontraksi jantung (pengaruh inotropik negatif) dan melambatkan perambatan impuls sepanjang sistem penghantaran jantung (pengaruh dromotropik negatif) (Kartolo, 1993). Pengaruh saraf simpatik terhadap jantung, yaitu meningkatkan frekwensi denyut jantung (pengaruh kronotropik positif), meningkatkan kuat kontraksi jantung (pengaruh inotropik positif), dan mempercepat perambatan impuls sepanjang sistem penghantaran impuls (pengaruh dromotropik positif) (Kartolo, 1993).

\section{Katak (Rana $S p)$}

Sistem peredaran darah pada katak terdiri dari jantung (cor), arteri, kapiler, vena, pembuluhpembuluh limpha, dan cairan darah dan limpha (Radiopoetro, 1983). Jantung terdiri dari tiga ruangan yaitu dua atrium dan satu ventrikel. Atrium telah terbagi dengan sepurna oleh septum interuariculum menjadi atrium kiri dan kanan (Nawangsari,1989 dan Milton Hildebrand,1982). Katak mempunyai sistem peredaran darah tertutup; dalam hal ini darah beredar sepanjang rangkaian pembuluh darah dari arteri ke vena melalui kapiler (Kartolo, 1993). Berdasarkan lintasannya peredaran darah pada katak dibagi menjadi dua bagian yaitu peredaran darah pendek (pulmoner), darah dari seluruh tubuh mengalir masuk ke sinus venosus dan kemudian mengalir menuju ke atrium kanan. Dari atrium kanan, darah mengelir ke ventrikel yang kemudian dipompa keluar melalui arteri pulmonalis menuju paru-paru (pulmo). Dari paru-paru darah keluar melalui vena pulmonalis menuju atrium kiri. Peredaran darah panjang (sistemik) yang lintasannya adalah dimulai dari ventrikel mengalir ke conus arteriosus selanjutnya ke aorta ventralis menuju ke seluruh tubuh. Darah dari seluruh tubuh darah dialirkan ke sinus venosus menuju atrium kanan (Kartolo, 1993).

Mencit (Mus musculus)

Struktur/anatomi jantung mencit diliputi oleh selaput pericardium. Yang terbagi atas empat ruangan dengan sempurna, yaitu: atrium kanan (atrium dekstra), atrium kiri (atrium sinistra), ventrikulus kanan (ventrikulus dekstra) dan ventrikulus kiri (ventrikulus sinistra) (Ayda. T.Y, dan Tatang Djuhanda 1990). Atas dasar lintasannya, peredaran darah mencit dibedakan menjadi dua macam yaitu: (1) Peredaran darah sistemik. Peredaran darah sistemik disebut juga peredaran darah panjang, yaitu dimulai ventrikel jantung kiri sampai atrium jantung kanan. Peredaran darah sistemik dimulai dari kontraksi ventrikel jantung kiri yang mengakibatkan darah bergerak atau mengalir ke aorta. Dari aorta darah akan mengalir melalui arteri, arteriol dan kapiler dari semua jaringan tubuh. Dari kapiler jaringan tubuh darah akan dialirkan kembali ke atrium jantung kanan (Kartolo, 1993 dan Sudarwati. S, 1992). Aliran darah di arteriol, kapilier, dan venula secara keseluruan dikenal sebagai sirkulasi mikro. Peredaran darah sistemik terdiri dari dua jaringan komunikasi yaitu jaringan arteri dan jaringan vena yang dihubungkan dengan kapiler. Kegunaan peredaran darah sistemik (Kartolo, 1993). Kegunaan peredaran darah sistemik adalah untuk membawa $\mathrm{O}_{2}$ dan zat makanan ke sel jaringan dan mengalirkan atau mengambil zat ampas (Kartolo, 1993 dan Agil, M. 1987). (2) Peredaran darah paruparu (pulmoner). Peredaran darah paru-paru disebut juga peredaran darah pendek karena lintasan aliran darahnya pendek, yaitu dimulai dari ventrikel jantung kanan sampai ke atrium jantung kiri. Peredaran darah paru-paru dimulai dengan kontraksi ventrikel jantung kanan yang mendorong darah yang ada padanya ke arteri pulmonalis yang kemudian mengalir ke kapiler paru-paru. Pada waktu mengalir ke paru-paru darah menerima banyak $\mathrm{O}_{2}$ dan membuang $\mathrm{CO}_{2}$. Dari paru-paru kemudian mengalir melalui vena pulmonalis menuju ke atrium jantung kiri (Ganong, 1983).

Tahap ke dua yaitu kegiatan praktekum, pada tahap ini dilakukan pembedahan hewan coba dengan menggunakan 10 ekor Mencit dan 10 ekor hewan coba Katak. Pembedahan dilakukan dengan cara: Hewan coba Mencit dan Katak yang dijadikan sampel dibius dengan kapas yang sudah dibasuh dengan klorofom, tusuk keempat kakinya dengan menggunakan jarum pentul pada papan bedah, selanjutnya rongga abdomen di bedah kearah rongga dada. Kemudian rongga dada/thorax dibedah sehingga kelihatan jantungnya, kemudian dengan menggunakan hand counter menghitung frekwensi denyut jantung per menit dan mengamati struktur morfologi jantungnya. Selama mengamati frekwensi denyut jantung hewan coba tersebut tetap diberikan larutan ringer supaya hewan coba tetap hidup (Sastradipradja.D, 1998 dan Nawangsari, 1989). Data kemudian dianalis untuk mendapatkan rerata frekwensi denyut jantung (Sugiyono.1997) . Dari hasil analisis data diperoleh rata-rata frekwensi denyut jantung sebesar 102 per menit, 
sedangkan rerata frekwensi denyut jantung Katak didapat sebesar 69 per menit.

\section{Kesimpulan}

Kegiatan pengabdian ini sangat bermanfaat bagi siswa Klas VII SMP Negeri 7 Mataram sebagai pengetahuan dan ketrampilan terkait dengan tehnik pembedahan hewan coba. Siswa telah memahami tehnik-tehnik pembedahan hewan coba, dapat melakukan pembedahan hewan coba dengan baik dan benar, serta mengetahui struktur jantung Katak dan Mencit. Hasil praktekum diperoleh Mencit memiliki rata-rata denyut jantung 102 per menit, sedangkan denyut jantung Katak reratanya 69 per menit

\section{Daftar Pustaka}

Agil, M. 1987. Pengaruh Daun Sauropus androgynus Terhadap Sekresi Air Susu Mencit Betina Yang Menyusui. Tesis Magister Sains. Fakultas Pascasarjana Universitas Airlangga Surabaya.

Ayda Tresnawaty. Y., dan Sri Sudarwati. 1992. Struktur Hewan. Fakultas Matematika dan Ilmu Pengetahuan Alam. Institut Teknologi Bandung.

Chukwuocha, R. U., Hartman, A. D. and Feeney, A. Z. 1994. Sequences of Fou New Members of the $\mathrm{VH}$ 7183Family in BALB/C Mice. Journal Immunogenetis. P.40:76-78.

Ganong, W.F. 1983 Fisiologi Kedokteran. Edisi ke 10. Terjemahan Adhi Dharma. ECG. Penerbit Buku Kedokteran Jakarta.

Kartolo. S. W. 1993. Fisiologi Hewan. Departemen Pendidikan Dan Kebudayaan Direktorat Jenderal Pendidikan Tinggi Proyek Pembinaan Tenaga Kependidikan Pendidikan Tinggi.

Milton Hildebrand. 1982. Analysis of Vertebrate Structure. New York

Nawangsari Sugiri. 1989. Zoologi. Departemen Pendidikan Dan Kebudayaan Direktorat Jenderal Pendidikan Tinggi Pusat Antar Universitas Ilmu Hayat Institut Pertanian Bogor
Radiopoetro. 1983. Zoologi. Penerbit Erlangga

Sastradipradja.D. 1998. Fisiologi Veteriner. Institut Pertanian Bogor

Sugiyono.1997. Statistik Untuk Penelitian. Bandung. CV Alfabeta.

Tatang Djuhanda. 1990. Analisa Struktur Vertebrata. Penerbit Armico Bandung. 